\title{
A Review Of The Determinants Of Long Run Share Price And Operating Performance Of Initial Public Offerings On The Johannesburg Stock Exchange
}

Chimwemwe Chipeta, University of the Witwatersrand, South Africa Adrian Jardine, University of the Witwatersrand, South Africa

\begin{abstract}
This paper provides some new evidence on the determinants of long run operating and share price performance of Initial Public Offerings (IPO) on the Johannesburg Stock Exchange (JSE). It has been hypothesised that the information contained in the pre listing documents could shed some light on the aftermarket performance of South African IPO shares. In line with previous literature, South African IPO shares significantly underperformed the market on average. Additionally, there is a statistically significant negative relationship between IPO Volume and long run performance, suggesting that the South African IPO market may be subject to the 'fads and over optimism' theory of Ritter (1991). The overoptimism hypothesis is further cemented by a negative correlation between pre IPO revenue forecast and aftermarket operating performance. Listing expenses play a moderate role in the reduction of the aftermarket performance of IPOs on the JSE. However, it appears that international investment banks have a positive influence on the aftermarket performance of IPOs on the JSE. Likewise, firms audited by the BIG 4 audit firms tend to perform well in terms of aftermarket buy and hold returns. Large firms at the time of listing tend to perform well and firms with high growth prospects at the time of listing generate a negative and significant return on their investment in total assets. Although the contingent liabilities disclosed in the prelisting reports negatively influence most of the measurers of aftermarket performance, the relationship is, by and large, insignificant.
\end{abstract}

Keywords: Initial Public Offerings; Johannesburg Stock Exchange; Cumulative Abnormal Returns

\section{INTRODUCTION}

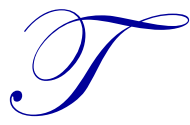

here are a number of studies that have documented a significant systematic increase from the offer price to the closing share price on the first day of trading. For example, Stoll and Curley (1970), Reilly (1973), and Ibbotson (1975) provide early evidence of systematic underpricing of Initial Public Offerings (IPOs). Related to this is the 'hot issue' market phenomenon, in which issues in certain time periods display abnormally higher short-run aftermarket performance than during other periods (first documented by Ibbotson \& Jaffe, 1975). Ritter (1991) and Loughran and Ritter (1995) also report evidence that in the long run, IPOs appear to be overpriced; the shares of issuing firms significantly underperform those of industry- and sizematched, non-issuing firms and the broad market for several years following an IPO. This phenomenon is not exclusive to the United States of America (USA, hereafter, US). For instance, short-run underpricing and/or long run underperformance of IPOs has been documented in the United Kingdom (UK) (Levis, 1993; Chambers \& Dimson, 2009), Germany (Gunther \& Rummer, 2011), Japan (Moshirian, Ng, \& Wu, 2010), and Australia (Lee, Taylor, \& Walter, 1996). Most importantly, for the purposes of this paper, similar patterns in IPO performance have been found in a number of emerging markets, for instance in China (Chan, Wang, \& Wei, (2004); Su \& Bangassa, (2011)) and in Brazil, Chile, and Mexico (Aggarwal, Leal, \& Hernandez, 1993). 
The South African literature has documented similar patterns in long run IPO performance. For instance, Page and Reyneke (1997) and M'Kombe and Ward (2002) document significant long run underperformance of IPOs on the Johannesburg Stock Exchange (JSE) for the 1980-1991 and 1980-1998 sample periods respectively. Alli, Subrahmanyam, and Gleason (2010) later examined the implications of financial liberalisation on JSE IPO data ranging from 1995 to 2004, and they document, inter alia, significant initial positive returns, suggesting high underpricing for the post liberalisation epoch. It appears from the South African literature that the issues relating to the degree of IPO underpricing and the long run underperformance of South African IPO shares have been well documented. However, the information contained in the prelisting documents of IPOs could help explain the long run performance of firms listing on the JSE. Hanley and Hoberg (2010) have demonstrated that the information contained in IPO prospectuses influences the valuation of IPO shares and the degree of underpricing. Pursuant to this argument, we conjecture that there are a number of factors contained in the IPO pre listing documents that could be linked to the aftermarket performance of IPOs on the JSE: Firstly, the magnitude of listing costs could have a significant bearing on the aftermarket performance of the listing company. These costs, albeit small relative to the size of the companies listing, could have been utilised for capitalising the business further, in order to enhance the future profitability of the firms. Secondly, the optimism reflected by revenue forecasts disclosed in the listing firms' prospectuses could be linked to long run underperformance of firms listing on the JSE. The overreaction, fads, and over optimism phenomenon identified by Ritter (1991) suggests that managers could overestimate the future performance of their firms. Thirdly, the disclosure of key material aspects such as contingent liabilities and litigation statements in the prospectuses could proxy for risk of an IPO, and this could negatively affect the aftermarket performance of listing firms. Lastly, the following firm level characteristics warrant further examination; the size of the board, age, firm size, and the domicile of the listing firm. These are some of the factors that have largely been ignored in the South African literature. Thus the main contribution of this paper is to provide alternative explanations to the factors that contribute to the long run aftermarket performance of IPOs on the JSE.

In line with other empirical studies, it is shown that, in the long run, South African IPO shares over the sample period significantly underperformed the market on average. Additionally, regression analyses reveal that there is a statistically significant negative relationship between long run performance (as measured by the return on equity) and both annual IPO volume and pre listing revenue forecast, suggesting that the South African IPO market may be subject to the 'fads and over optimism' theory of Ritter (1991). Listing expenses play a moderate role in the determination of the aftermarket performance of IPOs on the JSE. However, it appears that international investment banks have a positive influence on the aftermarket performance of IPOs on the JSE. Likewise, firms audited by the BIG 4 audit firms tend to perform well in terms of aftermarket buy and hold and benchmark adjusted returns. Large firms at the time of listing tend to perform well and firms with high growth prospects at the time of listing generate a negative and significant return on their investment in total assets. Although the contingent liabilities disclosed in the prelisting reports negatively influence most of the measurers of aftermarket performance, the relationship is, by and large, insignificant.

The rest of the paper is organised as follows: Section two reviews key academic literature on IPO performance around the world. Section three discusses the data and methodology used in the study. Section four reports the results of the paper, and Section five concludes the paper.

\section{LITERATURE REVIEW}

\subsection{International Evidence on Share-Price Performance of IPOs}

The issue of the systematic underpricing of IPOs has been widely documented in the literature. A number of early studies (See Stoll \& Curley (1970); Reilly (1973); and Ibbotson (1975)) document a systematic increase from the offer price to the closing share price on the first day of trading. In other words, initial public offerings on average earn systematically positive first-day returns. Ritter and Welch (2002) analyse 6,249 IPOs in the US for the period 1980-2001. They find that IPOs earn an average first-day return of 18.8\%, although the magnitude of underpricing varies across time. For example, average first-day returns to IPOs during the 1980-1989 sub-period were $7.4 \%$, while during the 1995-1998 sub-period, average first-day returns were substantially higher at $18.1 \%$. In fact, during the period of the 'internet bubble' (1999-2000), IPOs displayed average first-day returns of $65.0 \%$. Lowry, Officer, and Schwert (2010) examine the variability of IPO initial returns for a sample of 8,759 IPOs in the 
US and they find that initial returns exhibit substantial volatility, especially in hot issue markets, and that the variability of these returns fluctuates substantially over time.

Researchers have further documented that, in the long run, IPO shares underperform. For example, Ritter (1991) examines a sample of 1,526 IPOs in the US for the period 1975-1984, and reports three main issues; firstly, issuing firms substantially underperform a control portfolio of firms matched by size and industry from the closing price on the first day of public trading to their three-year anniversaries. Specifically, the average holding period return for this sample of IPOs of ordinary shares in the three years after going public (excluding initial returns) is $34.47 \%$, but a control sample of shares matched by size and industry earned an average return during the same threeyear holding period of $61.86 \%$. Secondly, as is the case with short-run performance, the pattern of long run performance of IPOs in the study is cyclical: firms issuing in high-volume years tend to display higher levels of long run underperformance. Finally, the pattern of long run IPO performance varies across industry: during the 19751984 sample period, oil and gas IPO shares performed particularly poorly, while those of banks and financial institutions displayed superior long run performance. Research in the US has also shown that IPO performance is driven by the quality of the venture capital partner and underwriter respectively. For example, Krishnan, Ivanov, Masulis, and Singh (2011) show that firms backed by reputable venture capital firms perform well in the long run. This is mainly because reputable venture capital firms continue to play a role in the corporate governance of the IPO firms following listing. In addition, Dong, Michel, and Pandes (2011) find that US IPOs backed by quality underwriters outperform IPOs backed by low quality underwriters. The authors further show that underwriter quality has a positive impact on the aftermarket performance of IPOs with high uncertainty. Further evidence suggests that IPO underperformance is influenced by acquisition activity by newly listed firms; Brau, Couch, and Sutton (2012) find that US IPOs that engage in acquisition activity in the first year after going public significantly underperform non-acquiring IPO firms. The authors report mean three-year buy and hold abnormal returns of $-15.6 \%$ for newly listed acquiring firms compared to returns of $5.9 \%$ for non-acquiring firms.

The patterns of IPO performance are not specific to the US. It is clear that short-run underpricing and long run underperformance of IPO shares is a truly global phenomenon. A significant body of international evidence supports this, although it is clear that the magnitude of short- and long run IPO performance varies across countries and time. For example, Levis (1993) reports average first day returns of $14.3 \%$ and significant long run underperformance relative to three alternative benchmarks over 36 months post-issue, for a sample of 712 IPOs in the UK from 1980-1988. In a later study, Levis (2011) finds that private equity backed IPOs perform better than venture capital backed and non-backed IPOs in the UK. In fact, the author finds that Private Equity backed IPOs' aftermarket returns remain positive and statistically significant over the sample period. Ljunqvist (1997) documents average first-day underpricing of $9.2 \%$ and market-adjusted returns of $-12.1 \%$ over three years post-issue for a sample of 189 German IPOs for the period 1970 to 1993. Gunther and Rummer (2011) further show that high initial returns are associated with long run underperformance for German firms that listed during the hot issue market of 1997 to 2001. Lee, Taylor, and Walter (1996) find evidence of significant positive first-day returns and poor three year share price performance (relative to the market) for a sample of 266 industrial IPOs in Australia from 19761989; and Moshirian, et al. (2010) finds evidence of short-run IPO underpricing in Hong Kong, Singapore, and Japan for the period between 1991 and 2004, with average first-day returns of $21.43 \%, 33.1 \%$, and $34.04 \%$ respectively.

Neither are these patterns of IPO performance specific to developed markets: importantly for the purposes of this study, similar evidence is found in a number of studies of IPOs in emerging markets. Aggarwal, Leal, and Hernandez (1993) find average first-day returns of 78.5\%, 16.7\%, and 2.3\%, and mean three year market-adjusted returns of $-47.0 \%,-23.7 \% \mathrm{~m}$ and $-19.6 \%$, for Brazil, Chile, and Mexico, respectively. For a sample of 570 Chinese A-share IPOs during the 1993-1998 period, Chan, Wang, and Wei (2004) find average first day returns of 178\% and slight long run underperformance relative to size- and book-to-market-matched portfolios.

\subsection{Explaining the Pattern of IPO Performance}

A number of theories exist as to why IPOs display short-run underpricing and long run underperformance. Short-run underpricing may result from information asymmetries between issuers and investors. Specifically, issuers may choose to 'leave money on the table' as a signal of firm quality (Ritter \& Welch, 2002), or because issuers want 
to avoid the situation where investors display characteristic 'herding' behaviour. Thus a negative informational cascade may render the issue a failure if the issue is perceived to be overpriced (Welch, 1992). Underpricing may also be a manifestation of efforts by the underwriter to induce information revelation from investors through the practice of 'bookbuilding' (Benveniste \& Spindt, 1989). This is done in order to compensate investors' fears of potential losses from a 'winner's curse' (Rock, 1986) or through attempts by the issuer to avoid potential future legal liability (Hughes \& Thakor, 1992). Researchers have also shown that IPO underpricing is affected by corporate governance and legal factors. For example, Boulton, Smart, and Zutter (2010) report that firms listing in countries with governance rules that strengthen the position of investors relative to corporate insiders underprice to create excess demand for the stock. This in turn generates a wider dispersion of shares, and consequently reduces the incentive to monitor the actions of corporate managers. In a related study, Engelen and Van Essen (2010) argue that this positive association between underpricing and the effectiveness of the legal system is implausible because, firstly, underpricing does not prohibit outside investors from accumulating a large block of shares. Secondly, with the exception of the US and UK, existing shareholders in many firms issuing in continental Europe and Asia retain most of the control following an IPO. They utilise the Hierarchical Linear Modelling technique to capture the relationship between the legal framework and the degree of underpricing for IPO firms in 21 countries, and they find that IPO firms underprice less in countries with stronger legal mechanisms.

The long run underperformance of IPO shares may similarly be due to a number of factors, for example higher agency costs once the firm is publicly traded (Jain \& Kini, 1994), and as a manifestation of managerial hubris and herding (Schultz, 2001). Brav and Gompers (1997) note that the measurement of long run performance is highly sensitive to the benchmark and econometric methodology used. Additionally, Ibbotson and Jaffe (1975) document a 'hot issue' market phenomenon. These are periods during which the number of companies going public and the average short-run share price performance of new issues are abnormally high. Further, Ritter (1991) finds that there is a positive relation between IPO volume and the level of long run underperformance over time. Higher levels of IPO long run underperformance are concentrated among young growth firms (which typically have higher marketto-book ratios than more established firms), and that IPO volume is negatively related to the discount on closed-end mutual funds (a proxy for investor sentiment). It is suggested that this is consistent with a pattern where firms issue to take advantage of windows of opportunity, where investors are overoptimistic and are willing to pay higher multiples for a given firm's share (and hence the pattern of short-run underpricing is observed).

After the IPO, managers may tend to overinvest as a result of excess funds available from the issue, a manifestation of Jensen's free cash flow hypothesis (Jensen, 1986), or by taking advantage of the firm's temporarily overvalued equity as 'cheap' currency to acquire assets (Myers \& Majluf, 1984). Subsequently, over the long run, the issuer may perform poorly as a result of this overinvestment. Ritter (1991) describes this explanation as the 'overoptimism and fads story'. The overoptimism phenomeneon has been documented in the literature by way of optimistic ex ante cash flow forecasts disclosed in IPO prospectuses; Cogliati, Paleari, and Vismara (2011) examine non-financial IPOs in France, Germany, and Italy, and they find that ex post cash flow growth rates do not justify the ambitious growth forecast documented in the listing firms' prospectuses. Most recently, Chan (2014) find a negative association between retail investor demand and long run abnormal returns of IPOs in the US. The author argues that this negative association is primarily driven by overoptimistic sentiment investors during the internet bubble period of 1999 to 2000 .

\subsection{IPO Performance in South Africa}

A limited number of studies have been conducted on IPO performance in the South African market. For example, Page and Reyneke (1997) examined the long run aftermarket performance of 118 offerings on the JSE for the period 1980-1991. They find that issuing firms underperform their relative listing sector indices and a sizematched portfolio of seasoned firms by an average of $18.4 \%$ and $13.1 \%$ per annum, respectively, over a four-year period post-issue. Their results also suggest that long run underperformance is more concentrated among smaller companies and companies that list in historically volatile industrial sectors.

M'Kombe and Ward (2002) extended the study of Page and Reyneke (1997) by examining a sample of 541 IPOs on the JSE for the period 1980-1998. Relative to three alternative benchmarks - the Capital Asset Pricing Model (CAPM), book-to-market tercile portfolios, and market capitalisation quintile portfolios, the authors find 
clear evidence of long run underperformance of IPOs in South Africa over 1, 3, 5, and 10 year holding periods. Moreover, a number of patterns in South African IPO performance are uncovered. Specifically, the listing price significantly influences aftermarket performance (with firms listing in the ' 500 cents or more' price range displaying the worst aftermarket performance); and firms that issue during 'hot market' periods display the worst aftermarket performance. On the other hand, the level of underpricing does not significantly influence aftermarket performance.

Auret and Britten (2008) further examined the post-issue operating performance of a sample of 391 firms that listed on the JSE between 1990 and 2003. Among other patterns, they find that although issuing firm profitability (as measured by return on assets) increases at the time of the IPO, it declines significantly after the third year post-issue. Furthermore, long-term investment (capital expenditure) increases in the year of the IPO, but falls in years 2 and beyond. This is consistent with a pattern where firms take advantage of windows of opportunity and issue during early stages of strong performance. However, this level of performance may not be sustainable. Managers may then tend to overinvest, and hence, on average, the performance of the issuing firm turns out to be disappointingly lower than expected in the long run.

\section{RESEARCH METHODOLOGY}

\subsection{Data}

The sample includes firms that have listed on the main board of the JSE between 01/01/1996 and $31 / 12 / 2010$. However, the sample is limited to those firms for which a usable prospectus was available. The sample period is restricted to 2010 because three years of post-issue share price returns and profitability measures are required in order to examine long run IPO performance. In order to mitigate a possible survivorship bias, the sample specifically includes delisted firms. Firms that listed on the JSE alternate exchange (AltX) are not included because these shares are not as liquid as the shares listed on the main board. Over this sample period, a total of 154 usable prospectuses were obtained from the McGregor Bureau for Financial Analysis (BFA) database.

Table 1 provides a breakdown of the number of issuing firms by year, over the sample period. ${ }^{1}$ It is apparent that the number of IPOs varies somewhat from year-to-year. The number of listings is dependent on the prevailing economic conditions. The listings increased in the years leading up to the year 2000, when the dot com bubble burst. Likewise, a steady rise in IPOs is observed in the period leading up to the global financial crisis of 2008.

Table 1: Annual IPO Volume on the JSE (1996-2010)

\begin{tabular}{lcc}
\hline Year & Number of IPOs & Proportion of Total Sample \\
\hline 1996 & 9 & 5.84 \\
\hline 1997 & 15 & 9.74 \\
\hline 1998 & 20 & 12.99 \\
\hline 1999 & 17 & 11.04 \\
\hline 2000 & 8 & 5.19 \\
\hline 2001 & 4 & 2.60 \\
\hline 2002 & 5 & 3.25 \\
\hline 2003 & 2 & 1.30 \\
\hline 2004 & 5 & 3.25 \\
\hline 2006 & 7 & 4.55 \\
\hline 2007 & 15 & 9.74 \\
\hline 2008 & 26 & 16.88 \\
\hline 2009 & 13 & 8.44 \\
\hline 2010 & 3 & 1.95 \\
\hline Total & 4 & 2.60 \\
\hline & 154 & $100.00 \%$ \\
\hline
\end{tabular}
${ }^{1}$ The number of listing firms in Table 1 represents the sampled firms, and not all the shares listing on to the JSE. However, the proportions are
indicative of the volumes of all IPO shares over the years. 


\subsection{Measuring the Long Run Performance}

Measuring the long run share price performance of IPOs is a complicated procedure, with some researchers (such as Loughran \& Ritter (1995) and Gompers \& Lerner (2003)) arguing that the magnitude of long run abnormal performance is highly sensitive to the methodology used. One particular issue in this regard is that there are a number of different benchmark methodologies used in order to evaluate long run performance, including the use of the CAPM, a multifactor model (such as that of Fama-French 3-factor regressions), or by benchmarking against the market and matching industries and firms. Indeed, this is quite a contentious issue: Ritter and Welch (2002) conclude that there is a distinct lack of consensus with respect to the proper measurement technique. Additionally, the length of the aftermarket period over which the share price performance is to be measured may influence the results. Another issue relates to whether to use Cumulative Average Abnormal Returns (CAARs), which ignore the effect of compounding, or Buy-and-Hold Abnormal Returns (BHARs), which include the effect of compounding (M'kombe \& Ward, 2002). In addition, one may measure returns in event time or calendar time and must choose between equally- or value-weighting abnormal returns (Franks, Harris, \& Titman, 1991).

It is evident that research into IPO share price performance faces a plethora of choices over methodology. In this paper, the long run performance is examined through the use of monthly Cumulative Average BenchmarkAdjusted Returns (CAARs), Buy and Hold Abnormal Returns (BHARs), Return on Total Assets (ROA), and Return on Book Value of Equity (ROE). In terms of CAARs, we follow the convention as per Ritter (1991), where the aftermarket period is defined to be the three years after the IPO, exclusive of the initial return period. The initial return period is defined to lie in month zero, and the aftermarket period includes the following 36 months, with months being measured in calendar, rather than event time. The calendar time approach in measuring returns yields valid statistical tests and is more consistent with a trading strategy (Bjerring, Lakonishok, \& Vermaelen, 1983). Further, Franks et al. (1991) contend for the use of calendar over event time because serial correlation is induced when portfolios are formed in event time.

Monthly benchmark-adjusted returns are calculated as the monthly raw return on a share minus the monthly benchmark return for the corresponding monthly period. For each issuing firm's share, four benchmarks are used; the JSE All Share Index, the Top 40 Index, the JSE Mid cap index, and the JSE Small Cap Index (J202). The first benchmark is a market capitalisation-weighted index that constitutes $99 \%$ of the market capitalisation of all firms listed on the JSE. The second benchmark consists of the top 40 JSE shares by market capitalisation. The third benchmark comprises the top 60 JSE shares (by market capitalisation) that are not included in the JSE Top 40 index. The fourth benchmark is a market capitalisation-weighted index made up of all the other shares that fall outside of the Top 40 and Mid Cap indices. The small firm index may be an appropriate benchmark given that issuing firms are generally smaller on average.

A few notes on these benchmarks are in order at this point. As Maritz (2003) points out, the JSE Top 40 and All Share indices are dominated by large resource firms: not only is risk highly concentrated in this market segment, but resource shares underperformed the equity market substantially during the 1990s. Thus, the Top 40 and All Share indices may not be appropriate benchmarks. To adjust for the resource effect, various ad hoc procedures have been employed in the South African asset management industry for benchmarking purposes (For example, down-weighting the mining and resource components of the All Share index). More recently, in 2002 the JSE formally introduced three new indices - the Capped All Share Index (J303), the Shareholder-Weighted All Share Index (J403), and an equally-weighted Top 40 index (J2EQ) - each of which, to some extent, compensate for the resource effect, and thus would be suitable market benchmarks for the purposes of this study.

Unfortunately, as these indices were only introduced in 2002, they are not available to benchmark IPO shares from the early part of the sample period (1996-2001), which make up a substantial part of the overall sample (see Table 1). Thus, this paper is restricted to using the All Share index, despite the implications of the resource effect. Due to this limitation, the Small Cap index is introduced as a benchmark in this paper. Although these indices track the performances of firms of a certain market-cap range only (and thus may not necessarily represent the broader market), the combination of results using these two benchmarks is likely to give a fairly robust indication of the performance of IPO shares relative to the market, being the purpose of this study. Although the All Share and Top 40 indices are highly correlated (See Table 7), the correlations between the rest of the indices are quite low 
suggesting that the magnitude of IPO performance is likely to differ between benchmarks, and so we should have a good indication of overall market-adjusted performance.

The use of this benchmarking methodology over a CAPM-based benchmark avoids the criticism by Van Rensburg and Robertson (2003) that beta is an inappropriate risk factor in describing the expected returns to JSEtraded shares. In addition, Ritter and Welch (2002) suggest that one should be wary of considering Fama-French factors to be equilibrium risk factors and using them as controls. Hence, this paper avoids this potential problem. Of course, all results obtained from the examination of long run performance in this paper must be strictly interpreted in the context of the benchmarks used, and inferences made appropriately.

For the purposes of calculating the average returns for descriptive analysis, CAARs are calculated using the following procedures: The average benchmark-adjusted returns for calendar month $\mathrm{t}$ on a portfolio of $\mathrm{n}$ shares are calculated as

$\mathrm{AR}_{\mathrm{t}}=\frac{1}{n} \sum_{i=1}^{n} a r_{i t}$

Cumulative average benchmark-adjusted (abnormal) returns (CAARs) from calendar month q to calendar month s are calculated as

$\mathrm{CAAR}_{\mathrm{q}, \mathrm{s}}=\sum_{t=q}^{s} A R_{t}$

An aftermarket period of 36 months is used, therefore $(q, s)=(1,36)$. Equally-weighted CAARs are used in line with Ritter (1991). When a firm in the portfolio is delisted, the portfolio return for the next month will be an equally-weighted average of the remaining firms in the portfolio. This applies to all benchmarks used. Thus calculating CAARs implicitly involves monthly rebalancing.

Positive CAARs imply IPO long run outperformance relative to the relevant benchmark, and vice-versa. Put another way, a finding of statistically insignificant (or zero) CAARs would imply that IPO shares did not perform significantly differently compared to the relevant benchmark. For this reason, the statistical significance of the CAAR relative to each benchmark is tested. Since the distribution of CAARs is found to be significantly nonnormal (in unreported analysis), the non-parametric Wilcoxon signed-rank test is used, and z-stats and p-values are correspondingly reported. The Buy and Hold Abnormal returns and measures of profitability (ROA and ROE) are discussed in the next section.

\subsection{Examining Cross-Sectional Patterns in IPO Performance}

In order to examine the cross-sectional patterns in the IPO share price performance, the following panel regression is used:

$R_{i, t}=V O L_{t}+S_{I Z E_{i, t}}+A P P L I S T_{i, t}+A G E_{i, t}+R E V F_{i, t}+L_{I S T C O S T}+t+B S_{i, t}+G R O W T H_{i, t}+D_{i} O M_{i}+$ $I N V B A N K_{i}+A U D I T Q_{i}+\mathrm{CONT}_{i}+I P O 1_{t}+I P O 2_{t}+I P O 3_{t}+e_{i}$

The dependent variable is denoted by $R_{i, t}$ which represents the aftermarket performance of the IPO. Two operating performance measures are used and three different measures are used to capture share price performance. The operating performance measures are $R O A_{i, t}$ and $R O E_{i, t} . R O A_{i, t}$ is the Return on Total Assets for firm $i$ at time $t$ and is calculated as earnings attributed to ordinary shareholders divided by total assets. $R O E_{i, t}$ is the Return on Total Equity for firm $i$ at time $t$ and is calculated as earnings attributed to ordinary shareholders divided by the book value of equity. The three share price performance measures are (i) three year buy and hold returns, (ii) three year market adjusted buy and hold returns using the JSE All Share Index as the market benchmark, and (iii) the three year size adjusted buy and hold returns, using the Small Cap Index as the market benchmark. The three year buy and hold return is calculated as follows:

$B H R_{i, t}=\prod_{1}^{n}\left(1+r_{i, t}\right)$ 
Where: $B H R_{i, t}$ is the annual buy and hold return for share $i$ at time $t$. The benchmark-adjusted buy and hold abnormal return for share $i$ at time $t$ is defined as:

$B H A R_{i, t}=B H R_{i, t}-B H R_{m, t}$

Where: $B H R_{i, t}$ is the annual buy and hold return on share $i$ at time $t$, and $B H R_{m, t}$ is the corresponding annual benchmark buy and hold return at time $t$.

The independent variables include measures that explain the aftermarket performance of IPOs. $V O L_{t}$ measures the effect of IPO volume on the aftermarket performance of IPOs, and is calculated as the number of IPOs in a given year as a percentage of the total number of IPOs in the sample period. SIZE $E_{i, t}$ measures the effect of the size (at the time of listing) on the aftermarket performance of the firm, and is calculated as the natural logarithm of total assets for firm $i$ at the time of listing. APPLIST ${ }_{i, t}$ is the total number of shares approved for listing as disclosed in the listing firm's prospectus and is calculated as the natural logarithm of total number of shares approved for listing. $A G E_{i, t}$ measures the effects of the listing firm's age at the time of listing on aftermarket performance, and is calculated as the number of years the firm has operated prior to listing. $R E V F_{i, t}$ is the annual revenue forecast of the firm prior to listing. It is measured as the difference between the one year forecasted revenue and the current revenue disclosed in the prospectus, divided by 100. LISTCOST $_{i, t}$ is the listing cost incurred by the firm as shown in the prospectus and is calculated as the natural logarithm of listing cost. ${ }^{2} B S_{i, t}$ represents the size of the board for firm $i$ at the time of listing, and is calculated as the total number of board members at the time of listing. GROWTH $_{i, t}$ measures the listing firm's growth prospects and is the market to book ratio of firm $i$ at time $t$ and is calculated as the closing market value per share divided by the book value per share on the day of listing.

Several dummy variables have been included to capture the effects of a number of factors on the aftermarket performance of the IPOs. The $D O M_{i}$ variable represents the domicile of the firm. A value of one is assigned to a foreign firm listing on to the JSE and zero for firms that are registered in South Africa. INVBANK captures the effects of the sponsoring firm on the aftermarket performance of the IPO. A value of one is assigned to international investment banks, and zero for local investment banks. ${ }^{3} A U D I T Q_{i}$ represents the quality of the auditing firm, and takes on the value of one for the BIG 4 Audit firms and zero, otherwise. $C O N T_{i}$ is assigned the value of one for firms that have disclosed a contingent liability and/or a litigation statement in the prospectus and zero otherwise. IPO $1_{t}, I P O 2_{t}$ and $I P O 3_{t}$ are dummy variables that capture the effects of the post issuing years on the performance of the IPOs.

The analysis is carried out using the Fixed and Random Effects regressions. The regressions were run using Stata software version 11. The Hausman (1978) specification test is used to determine which of the two models is suitable. For all the regressions, we fail to reject the null hypothesis that the residuals in the Random Effects Model are uncorrelated with the regressors. Hence, the model is estimated using the Random Effects regression, with standard errors robust to panel specific heteroscedasticity. The correlation matrix (Table 5) shows that the correlations between the variables are small; hence multicollinearity is not a concern.

\section{RESULTS AND DISCUSSION}

\subsection{Descriptive Analysis}

As shown in Table 2, the average age of a listing firm is 19.68 years, the average number of shares approved for listing is 198,093,267 shares, and the average board size is 8.02 directors. This is in line with the findings of Baker and Gompers (2003) who reported an average number of 6 directors for a sample of 1,116 IPO firms in the United States of America. The average cost of listing is R8 033725.27 and the average revenue forecast is $49.73 \%$. Table 3 reports the revenue forecast for each economic cycle. The highest forecasts are recorded during the period of 1996 to 1999 , which coincides with the period leading up to the internet bubble of the late 1990s.

\footnotetext{
${ }^{2}$ An alternative measure for listing costs is calculated as listing cost as a percentage of the market capitalisation of the listing firm. The results using this variable are similar.

${ }^{3}$ The international investment banks selected were the top ten international investment banks by market share
}

Copyright by author(s); CC-BY 
Listing firms were forecasting revenues of around 59.51\%. The period of 2000 to 2007 coincided with steady economic growth leading up to the global financial crisis of 2008, and revenue forecasts during this period were $52.99 \%$. The forecasts during the period of the global financial crisis (2008-2010) dramatically reduced to around $6.45 \%$, thus suggesting that the crisis dampened the growth forecasts for that period. Table 4 reports the average firm specific variables for the first three years after listing. The average growth prospects of the listing firms decline over time from 4.51 to 1.71 . Similarly, the average profitability of the listing firm (measured by ROA) declines in the period subsequent to the listing. Although the ROE increases following listing, it is still negative. The average size of the listing firm is increases steadily over the years from R2.421 billion to R3.076 billion. The average buy and hold, market and size adjusted buy and hold returns are positive in the first year following listing. However, in the second and third years, these returns are negative.

Table 2: Average Values for Selected Variables

\begin{tabular}{lc}
\hline \multicolumn{1}{c}{ Average Variables } & Average Values \\
\hline Average Age & 19.68 Years \\
Approved Listing Shares & 198093267 Shares \\
Average Board Size & 8.02 Directors \\
Average Listing Cost & R8 033 725.27 \\
Average Revenue Forecast & $49.73 \%$ \\
\hline
\end{tabular}

Table 3: Average Revenue Forecast per Economic Cycle Average Revenue Forecast

\begin{tabular}{lcccc}
\hline & Full Sample & $\mathbf{1 9 9 6 - 1 9 9 9}$ & $\mathbf{2 0 0 0 - 2 0 0 7}$ & $\mathbf{2 0 0 8 - 2 0 1 0}$ \\
\hline Percentage & $49.73 \%$ & $59.51 \%$ & $52.99 \%$ & $6.45 \%$ \\
\hline
\end{tabular}

Table 4: Average Variables for the Post Issuing Period

\begin{tabular}{lccccccc}
\hline & GROWTH & ROA & ROE & SIZE (R000) & BHR & BHARm & BHARs \\
\hline Year 1 & 4.51 & 0.01 & -0.26 & 2421240.74 & 0.00 & 0.00 & 0.02 \\
Year 2 & 2.34 & -0.05 & -0.19 & 2763292.71 & -0.06 & -0.06 & -0.05 \\
Year 3 & 1.71 & -0.09 & -0.01 & 3076828.77 & -0.03 & -0.02 & -0.01 \\
\hline
\end{tabular}

Table 5: Correlation Matrix for all the Variables

\begin{tabular}{|c|c|c|c|c|c|c|c|c|c|c|c|c|c|}
\hline & VOLUME & AGE & APPLIST & LISTCOST & BOD & FORECAST & SIZE & GROWTH & BHR & BHARm & BHARs & ROA & ROE \\
\hline VOLUME & 1.0000 & & & & & & & & & & & & \\
\hline AGE & -0.0588 & 1.0000 & & & & & & & & & & & \\
\hline APPLIST & $-0.2339^{*}$ & $0.1276^{*}$ & 1.0000 & & & & & & & & & & \\
\hline LISTCOST & $-0.1395^{*}$ & $0.1425 *$ & $0.1187^{*}$ & 1.0000 & & & & & & & & & \\
\hline BS & $-0.0982^{*}$ & $0.1212 *$ & $0.1316^{*}$ & $0.2354 *$ & 1.0000 & & & & & & & & \\
\hline REVFOR & $0.1779^{*}$ & $-0.1142 *$ & 0.0022 & -0.0314 & $-0.1412 *$ & 1.0000 & & & & & & & \\
\hline SIZE & -0.0177 & $0.2712^{*}$ & $0.1093 *$ & $0.1558^{*}$ & $0.0961^{*}$ & -0.0872 & 1.0000 & & & & & & \\
\hline GROWTH & -0.0371 & -0.0666 & 0.0545 & 0.0061 & 0.0074 & -0.0469 & 0.0849 & 1.0000 & & & & & \\
\hline BHR & $-0.2343^{*}$ & 0.0390 & 0.0924 & 0.0221 & $0.1620 *$ & $-0.0970 *$ & $0.0943 *$ & 0.0547 & 1.0000 & & & & \\
\hline BHARm & $-0.2298^{*}$ & 0.0404 & 0.0849 & 0.0168 & $0.1593 *$ & -0.0890 & $0.0941^{*}$ & 0.0548 & $0.9949 *$ & 1.0000 & & & \\
\hline BHARs & $-0.2285^{*}$ & 0.0393 & 0.0769 & 0.0152 & $0.1564 *$ & $-0.1014 *$ & $0.0981^{*}$ & 0.0554 & $0.9928 *$ & $0.9882 *$ & 1.0000 & & \\
\hline ROA & -0.0504 & 0.0459 & 0.0440 & 0.0511 & $0.0920 *$ & -0.0583 & $0.1341 *$ & 0.0186 & $0.1381 *$ & $0.1394 *$ & $0.1410^{*}$ & 1.0000 & \\
\hline ROE & $-0.0954^{*}$ & 0.0381 & $0.1027 *$ & 0.0157 & 0.0014 & -0.0719 & 0.0665 & -0.0205 & $0.0938 *$ & $0.0946 *$ & $0.0958 *$ & $0.3071 *$ & 1.0000 \\
\hline
\end{tabular}

\section{Empirical Results}

\subsection{Long Run Share Price Performance of IPOs}

Table 6 presents estimated CAARs for the 36 month aftermarket period according to benchmark, as well as the results of a statistical test of the significance of these CAARs reported in the form of p-values. These results suggest that, relative to all of the market benchmarks, ${ }^{4}$ IPOs clearly underperformed. For each benchmark, CAARs are negative and statistically significantly different from zero at the $1 \%$ significance level (given p-values of $<0.01$ for each).

\footnotetext{
${ }^{4}$ We include the Mid Cap and Top 40 indices for illustrative purposes.
} 
Table 6: CAARs for IPO shares

\begin{tabular}{lll}
\hline \multicolumn{1}{c}{ Benchmark } & CAAR(1,36) & Z-stat \\
\hline All Share & $-52.01 \% *$ & -5.935 \\
\hline Top 40 & $-53.43 \% *$ & -6.019 \\
\hline Mid Cap & $-44.06 \% *$ & -5.462 \\
\hline Small Cap & $-33.91 \% *$ & -5.183 \\
\hline * Statistically significantly different from zero at the 1\% significance level
\end{tabular}

Figure 1 graphically displays the time series pattern of the CAARs, as well as cumulative average raw (unadjusted) returns, for the full sample of issuing shares. Looking first at raw returns, IPO shares delivered an average return over a 36-month aftermarket period of $6.52 \%$ on a cumulative basis. This implies that investing in a portfolio of IPO shares would not have lost money in absolute terms. However, relative to the benchmarks, the full sample of IPOs clearly performed poorly over the period. Relative to the two broad market indices, the All Share and the JSE Top 40, IPO shares delivered CAARs of $-52.01 \%$ and $-53.43 \%$, respectively. The fact that these CAARs are very close in value is hardly surprising, given the extremely high correlation $(>0.99)$ between these two indices (see Table 7). This high correlation would suggest that large firms (by market cap) dominate the performance of the All Share index, which once again is not surprising given the implications of the resource effect and the fact that it is a market capitalisation-weighted index. As a consequence of this, as can be seen in Figure 1, the CAAR plots for these two benchmarks almost perfectly track each other.

Table 7: Matrix of Correlation Coefficients Between Monthly Benchmark Index Returns

\begin{tabular}{lcccc}
\hline & ALL SHARE & TOP 40 & MID CAP & SMALL CAP \\
\hline ALL SHARE & 1.0000 & 0.9954 & 0.7311 & 0.0291 \\
\hline TOP 40 & 0.9954 & 1.0000 & 0.6685 & 0.0089 \\
\hline MID CAP & 0.7311 & 0.6685 & 1.0000 & 0.1443 \\
\hline SMALL CAP & 0.0291 & 0.0089 & 0.1443 & 1.0000 \\
\hline
\end{tabular}

Focusing next on performance relative to the Small Cap and Mid Cap benchmarks, the full sample of IPO shares delivered CAARs of $-33.91 \%$ relative to the Small Cap index and $-44.06 \%$ relative to the Mid Cap index. Thus, relative to small and medium shares, as measured by market capitalisation, IPO shares significantly underperformed on average, although not as much as compared to the broader market-based benchmarks (All Share/Top 40). As Table 7 indicates, the Small Cap and All Share/Top 40 indices display very low correlations, of close to zero. Therefore, we would expect that the magnitude of IPO performance relative to these benchmarks to be quite different in size. A similar conclusion is reached for the Mid Cap benchmark, given its fairly high (but nonperfect) correlation with the All Share/Top 40 indices.

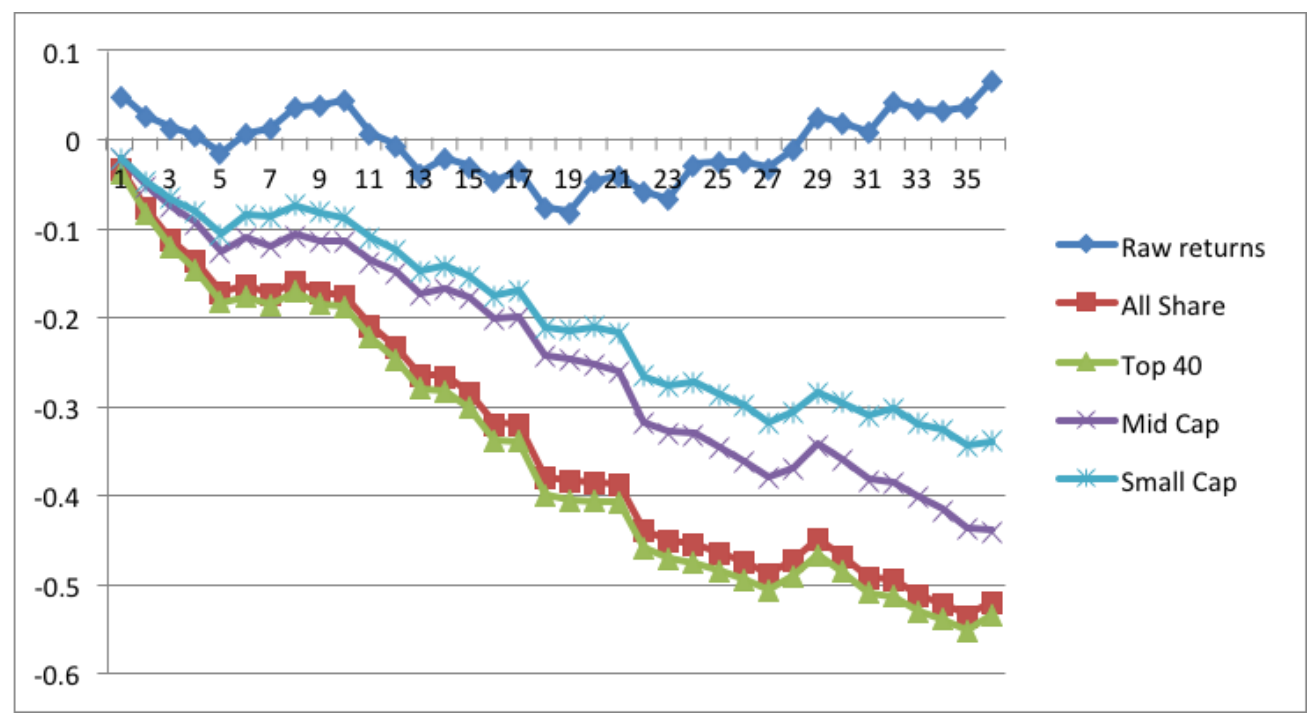

Figure 1: Full-Sample CAARs for IPO Shares 
Further examination of Figure 1 reveals that although the magnitude of the long run performance differs according to the benchmark used, the time-series pattern of CAARs is, in fact, very similar across benchmarks. Indeed, this is confirmed by Table 6, which displays the correlation coefficients of the CAARs of IPO shares across benchmarks. These correlations are very high (the lowest is 0.9202, between Top 40- and Small Cap-adjusted CAARs). This provides evidence that in absolute terms, underperformance is, to a large extent, consistent across benchmarks for the full sample.

To summarise, the evidence suggests that, relative to the benchmarks used, South African IPO shares for the sample period show significant long run underperformance relative to the market on average, although the magnitude of underperformance varies across benchmarks. Overall, these IPO shares performed better, although still quite poorly, relative to all the benchmark indices.

\subsection{Cross-Sectional Patterns in IPO Share Price Performance}

In order to investigate the cross-sectional patterns in IPO share price performance, a regression analysis was performed. Table 8 reports the cross sectional patterns in IPO performance. Consistent with the "fads and overoptimism" hypothesis, firms that list in high volume years tend to underperform in the long run. The results are consistent across the different measures of performance. The associated coefficient on the VOL variable for the different performance measures is negative and statistically significant at the 1 percent level for the three year buy and hold returns. The coefficient on the ROE regression is negative and significant at the 5 percent level, and the coefficient for the ROA regression is also negative, but insignificant.

Table 8: Regression Outputs for the Determinants of IPO Aftermarket Performance

\begin{tabular}{|c|c|c|c|c|c|}
\hline & ROA & ROE & BHR & BHARm & BHARs \\
\hline VOL & -0.3937 & $-1.1681 * *$ & $-3.4668 * * *$ & $-3.4501 * * *$ & $-3.3911 * * *$ \\
\hline AGE & 0.0148 & 0.0037 & 0.0603 & 0.0707 & 0.0685 \\
\hline APPLIST & 0.0190 & 0.1208 & -0.0001 & -0.0094 & -0.0193 \\
\hline LISTCOST & -0.0082 & -0.0934 & $-0.0968 *$ & $-0.1043 *$ & $-0.1077 *$ \\
\hline BS & 0.0046 & $-0.0366^{*}$ & $0.0411 *$ & $0.0407 *$ & 0.0389 \\
\hline DOM & -0.1622 & 0.1208 & 0.0206 & 0.0364 & 0.0983 \\
\hline CONT & -0.0749 & 0.0189 & -0.1327 & -0.1431 & -0.1505 \\
\hline INVBANK & $0.0289 * *$ & $0.0451 * * *$ & 0.0411 & 0.0376 & 0.0390 \\
\hline AUDITQ & -0.1076 & -0.2464 & 0.2648 & $0.2969 *$ & 0.2831 \\
\hline REVFOR & -0.0163 & $-0.0531 *$ & -0.0168 & -0.0081 & -0.0188 \\
\hline SIZE & $0.0620 * *$ & $0.1920 * * *$ & 0.0550 & 0.0524 & 0.0600 \\
\hline GROWTH & $-0.0017 *$ & -0.0057 & 0.0069 & 0.0070 & 0.0071 \\
\hline IPO1 & 0.0041 & 0.0430 & -0.0385 & -0.0262 & -0.0405 \\
\hline IPO2 & 0.0077 & 0.2061 & -0.0483 & -0.0520 & -0.0545 \\
\hline IPO3 & (omitted) & (omitted) & (omitted) & (omitted) & (omitted) \\
\hline Observations & 347 & 347 & 423 & 423 & 423 \\
\hline Prob > chi2 & 0.0015 & 0.0000 & 0.0000 & 0.0000 & 0.0000 \\
\hline R-Squared & 0.1214 & 0.1571 & 0.1393 & 0.1390 & 0.1418 \\
\hline Hausman (Prob > chi2) & 0.4805 & 0.1765 & 0.9042 & 0.8715 & 0.8485 \\
\hline
\end{tabular}

Notes: This table reports the regression results of the determinants of IPO aftermarket performance on the JSE. ROA is the return on total assets for firm $i$ at time $t$ and is calculated as earnings attributed to ordinary shareholders divided by total assets. ROE is the return on total equity for firm $i$ at time $t$ and is calculated as earnings attributed to ordinary shareholders divided by the book value of equity. BHR is the buy and hold return for firm i at time t. BHARm is the market (JSE All Share Index) adjusted buy and hold return for firm i at time t. BHARs is the small cap adjusted buy and hold return for firm $\mathrm{i}$ at time t. VOL is calculated as the number of IPOs in a given year as a percentage of the total number of IPOs in the sample period. AGE is calculated as the number of years the firm has operated prior to listing. APPLIST is the total number of shares approved for listing as disclosed in the listing firm's prospectus. LISTCOST is calculated as the natural logarithm of listing cost. BS is the board size and is calculated as the total number of directors for each listing firm. DOM is a dummy variable that represents the domicile of the listing firm. CONT is a dummy variable that identifies listing firms with disclosed contingent liabilities. INVBANK is a dummy variable that identifies firms backed by international investment banks. AUDITQ is a dummy variable that identifies listing firms that are audited by the BIG4 audit firms. REVFOR is calculated as the difference between the one-year forecasted revenue and the current revenue disclosed in the prospectus, divided by 100. SIZE is calculated as the natural logarithm of total assets for firm i at the time of listing GROWTH is calculated as the closing market value per share divided by the book value per share on the day of listing and IPO1, IPO2, and IPO3 are dummy variables that capture the effects of the post issuing years on the performance of the IPOs.*,***** denotes statistical significance at the $10 \%, 5 \%$, and $1 \%$ levels respectively. 
Moving on to listing expenses, as expected, a negative and statistically significant coefficient is reported for all measures of aftermarket share price performance. The coefficient is significant at the 10 percent level. However, the coefficients on the measures of operating performance are insignificant, albeit negative. This suggests that listing expenses play a mild role in the determination of the aftermarket performance of IPOs on the JSE. The size of the board, by and large contributes positively to the aftermarket share price performance of the IPOs, as evidenced by the positive coefficients on the performance measures. This observation confirms that firms with larger board sizes tend to perform well. However, in terms of ROE, the opposite sign occurs suggesting that firms with more members on the board generate negative returns on equity investment. Thus in line with Yermack (1996), firms with larger members of the board perform poorly in terms of market valuation. This could be attributed to the further complexity and the associated marginal costs arising from the increase in the number of board of directors. Further, it appears that international investment banks have a positive influence on the aftermarket performance of IPOs on the JSE. Specifically, the coefficient on the INVBANK variable is statistically significant at the 5 percent level for the ROA regression and significant at the $1 \%$ level for the ROE regression. The rest of the coefficients are positive but insignificant. This observation may indicate that the reputation of the investment bank could have positive long run effects on the aftermarket performance of IPO firms. This result is consistent with the findings by Dong et al. (2011) and Su and Bangassa (2011) that underwriter quality plays a significant role in improving the aftermarket performance of IPOs. In unreported analysis, the INVBANK variable is interacted with the SIZE and AGE variables respectively. The coefficient on the interactive term for the INVBANK and SIZE is positive and statistically significant at the five percent level for the ROA and ROE regressions. Thus, large firms that are backed by international investment banks perform well in the long run. ${ }^{5}$ Likewise, firms audited by the BIG 4 audit firms tend to perform well in terms of aftermarket buy and hold and benchmark adjusted returns. However, the relationship is mildly significant for the market adjusted buy and hold returns.

As alluded to earlier, firms that provide optimistic revenue forecasts, prior to listing tend to underperform, both in terms of operating and financial performance. The significant underperformance is however confined to the ROE estimate of profitability. The result is statistically significant at the 5 percent level. This result corroborates the finding of Cogliati et al. (2011) that IPO firms overestimate their aftermarket growth prospects. Further, Auret and Britten (2008) argue that firms usually list after a period of superior performance. It is likely that this exceptional pre listing performance causes managers to overestimate their future profit forecasts. In unreported analysis, we further investigate the effects of overoptimistic forecasts in high volume years. We create a dummy variable to capture firms with optimistic revenue forecasts that are above $17.9 \%$ (The median forecast). This dummy variable is interacted with the VOL variable. The coefficient on the interactive term is negative and statistically significant at the 5\% level. This shows that firms with overoptimistic revenue forecasts in high volume years tend to underperform significantly in the long run. Following the finding by Ritter (1991) that firms that list in high volume years tend to underperform in the long run, this underperformance could be linked to high and overoptimistic revenue forecasts.

The size of the company at the time of listing is a strong predictor of aftermarket performance of IPOs on the JSE. The coefficient on the SIZE variable is positive and statistically significant at all conventional levels indicating that large firms listing on the JSE perform well in the long run. However, the coefficient on the SIZE variable for the buy and hold and benchmark adjusted buy and hold returns is positive but insignificant. The plausible explanation for this finding is that large firms tend to have a reputation in the market place and the positive and significant correlation between size and age as reported in the correlation matrix (Table 5) suggests that large firms are also older. Further, firms with high growth prospects also perform well in terms of ROE. The associated coefficient is significant at all conventional levels. On the contrary, the opposite sign appears for the rest of the regressions, although not significant. The growth prospects of the firms play a mild role in explaining the aftermarket performance of the IPOs. In terms of ROA, the coefficient on the growth variable is negative and significant at the 10 percent level. This result indicates that firms with high growth prospects at the time of listing generate a negative return on their investment in total assets. Overall, the coefficients on the dummy variables IPO1 and IPO2, are all insignificant, suggesting that time effects have no significant impact of the aftermarket performance on IPO firms.

5 The coefficients on the interactive terms for INVBANK and AGE are positive but insignificant. Other interactions between AUDITQ and SIZE and AUDITQ and AGE also reported insignificant coefficients. 


\section{CONCLUSIONS AND RECOMMENDATIONS FOR FURTHER STUDIES}

This paper examined the determinants of long run share price and operating performance of IPOs on the JSE. The study was motivated by the a priori expectation that the information contained in the pre listing documents could help provide alternative explanations to the factors that drive IPO performance on the JSE. The event study methodology was adopted for the purpose of estimating the cumulative average abnormal returns for the purposes of establishing the aftermarket share price performance relative to key benchmarks. Further panel data estimation techniques and were used to test the effects of pre listing firm level characteristics and market conditions on the aftermarket performance of IPOs on the JSE for the period 1999 to 2010.

Measured over a 36 month aftermarket period, South African IPO shares clearly significantly underperformed the market on average over the sample period. The magnitude of underperformance varies according to the benchmark index used, with benchmark-adjusted returns of $-52.01 \%,-53.43 \%,-44.06 \%$, and $33.91 \%$ relative to the All Share, Top 40, Mid Cap, and Small Cap indices respectively. Finally, regression analysis revealed several cross-sectional patterns in South African IPO aftermarket performance over the period. Firms that listed in high-volume years tended to experience significantly poorer aftermarket performance. Further, firms that forecasted high revenue estimates tended to perform poorly. Thus, the pattern of IPO share price performance in South Africa over this period is somewhat consistent with Ritter's (1991) 'fads and overoptimism' hypothesis.

Listing expenses play a mild role in the determination of the aftermarket performance of IPOs on the JSE. However, it appears that international investment banks have a positive influence on the aftermarket performance of IPOs on the JSE. Likewise, firms audited by the BIG 4 audit firms tend to perform well in terms of aftermarket buy and hold and benchmark adjusted returns. Large firms at the time of listing tend to perform well and firms with high growth prospects at the time of listing generate a negative and significant return on their investment in assets. Although the contingent liabilities disclosed in the prelisting reports negatively influence most of the measurers of aftermarket performance, the relationship is insignificant.

This paper has opened up avenues for future research on IPOs is South Africa and the rest of the African continent. Research on IPOs should be extended to select African stock markets that have a sufficient coverage of liquid shares. The patterns of IPO underpricing and performance in these stock markets could be driven by, inter alia, country specific characteristics such as the strength of the legal and corporate governance mechanisms and the sophistication of the financial markets in these countries.

\section{AUTHOR INFORMATION}

Chimwemwe Chipeta is an Associate Professor of Corporate Finance at the University of the Witwatersrand in Johannesburg, South Africa. He has also published in peer reviewed journals focusing on capital structure and event studies. E-mail: chimwemwe.chipeta@ wits.ac.za (Corresponding author)

Adrian Jardine is a Finance Masters Graduate from the School of Economic and Business Sciences, University of the Witwatersrand, Johannesburg, South Africa. E-mail: jardine.adrian@gmail.com

\section{REFERENCES}

1. Aggarwal, R., Leal, R., \& Hernandez, L. (1993). The aftermarket performance of initial public offerings in Latin America. Financial Management, 22(1), 42-53.

2. Auret, C., \& Britten, J. (2008). Post-issue operating performance of firms listing on the JSE. Investment Analysts Journal, 68, 21-29.

3. Alli, K. L., Subrahmanyam, V., \& Gleason, K. C. (2010). Short and long run performance of initial public offerings in post-apartheid South Africa. Journal of African Business, 11(1), 1-25.

4. Baker, M., \& Gompers, P. A. (2003). The determinants of board structure at the initial public offering. Journal of Law and Economics, 46(2), 569-598.

5. Benveniste, L., \& Spindt, P. (1989). How investment bankers determine the offer price and allocation of new issues. Journal of Financial Economics, 24(2), 343-362. 
6. Brav, A., \& Gompers, P. (1997). Myth or reality? The long run underperformance of initial public offerings: Evidence from venture and non venture capital-backed companies. The Journal of Finance, 52(5), 1791-1821.

7. Brau, J. C., Couch, R. B., \& Sutton, N. K. (2012). The desire to acquire and IPO long-run underperformance. Journal of Financial and Quantitative Analysis, 47(3), 493-510.

8. Bjerring, J. H., Lakonishok, J., \& Vermaelen, T. (1983). Stock prices and financial analysts' reccommendations. The Journal of Finance, 38(1), 187-204.

9. Boulton, T. J., Smart, S. B., \& Zutter, C. J. (2010). IPO underpricing and international corporate governance. Journal of International Business Studies, 41(2), 206-222.

10. Chambers, D., \& Dimson, E. (2009). IPO underpricing over the very long run. The Journal of Finance, 64(3), 1407-1443.

11. Chan, K., Wang, J., \& Wei, K. C. J. (2004). Underpricing and long-term performance of IPOs in China. Journal of Corporate Finance, 10(3), 409-430.

12. Chan, Y. (2014). How does retail sentiment affect IPO returns? Evidence from the internet bubble period. International Review of Economics and Finance, 29(1), 235-248.

13. Cogliati, G. M., Paleari, S., \& Vismara, S. (2011). IPO pricing: Growth rates implied in offer prices. Annals of Finance, 7(1), 53-82.

14. Dong, M., Michel, J. S., \& Pandes, J. A. (2011). Underwriter quality and long run IPO performance. Financial Management, 40(1), 219-251.

15. Engelen, P., \& Van Essen, M. (2010). Underpricing of IPOs: Firm-, issue- and country-specific characteristics. Journal of Banking and Finance, 34(8), 1958-1969.

16. Franks, J., Harris, R., \& Titman, S. (1991). The Post-Merger Share-Price Performance of Acquiring Firms. Journal of Financial Economics, 29(1), 81-96.

17. Gompers, P.A., \& Lerner, J. (2003). The really long run performance of initial public offerings: The PreNasdaq evidence. The Journal of Finance, 58(4),1355-1392

18. Gunther, S., \& Rummer, M. (2011). The hot issue period in Germany: What factors drove IPO underpricing? Initial Public Offerings: An International Perspective of IPOs. Butterworth-Heinemann: Burlingham, Massachusetts.

19. Hanley, K.W., \& Hoberg, G. (2010). The information content of IPO prospectuses. Review of Financial Studies, 23(7), 2821-2864.

20. Hausman, J. A. (1978). Specification Tests in Econometrics. Econometrica, 46(6), 1251-1272.

21. Hughes, P., \& Thakor, A. (1992). Litigation risk, intermediation, and the underpricing of initial public offerings. Review of Financial Studies, 5(4), 709-742.

22. Ibbotson, R., \& Jaffe, J. (1975). 'Hot issue' markets. The Journal of Finance, 30(4), 1027-1042.

23. Ibbotson, R. (1975). Price performance of common stock new issues. Journal of Financial Economics, 2(3), 235-272.

24. Jain, B., \& Kini, O. (1994). The post-issue operating performance of IPO firms. Journal of Finance, 49(5), 1699-1726.

25. Jensen, M. (1986). Agency costs of free cash flow, corporate finance, and takeovers. American Economics Review, 76(2), 323-329.

26. Krishnan, C. N. V., Ivanov, V. I., Masulis, R. W., \& Singh, A. K. (2011). Venture capital reputation, postipo performance, and corporate governance. Journal of Financial and Quantitative Analysis, 46(5), 1295 1333.

27. Lee, P., Taylor, S., \& Walter, T. (1996). Australian IPO underpricing in the short and long run. Journal of Banking and Finance, 20(7), 1189-1210.

28. Levis, M. (1993). The long run performance of initial public offerings: The UK experience 1980-1988. Financial Management, 22(1), 28-41.

29. Levis, M. (2011). The performance of private equity-backed IPOs. Financial Management, 40(1), $253-277$.

30. Ljungqvist, A. (1997). Pricing initial public offerings: Further evidence from Germany. European Economic Review, 41(7), 1309-1320.

31. Loughran, T., \& Ritter, J. (1995). The new issues puzzle. The Journal of Finance, 50(1), 23-51.

32. Lowry, M., Officer, M. S., \& Schwert, W. G. (2010). The variability of IPO initial returns. The Journal of Finance, 65(2), 2010. 
33. M'Kombe, K., \& Ward, M. (2002). Aftermarket performance of initial public offerings on the JSE. Investment Analysts Journal, 55, 7-20.

34. Maritz, J. (2003). The capped- and shareholder-weighted indices: A quantitative comparison of different pension fund equity benchmarks. Cadiz Quantitative Research, 2003/07/5.

35. Moshirian, F., Ng, D., \& Wu, E. (2010). Model specification and IPO performance: New Insights from Asia. Research in International Business and Finance, 24(1), 2010.

36. Myers, S., \& Majluf, N. (1984). Corporate financing and investment decisions when firms have information that investors do not have. Journal of Financial Economics, 13(2), 187-221.

37. Page, M., \& Reyneke, I. (1997). The timing and subsequent performance of IPOs on the Johannesburg Stock Exchange. Journal of Business Finance and Accounting, 24(9, 10), 1401-1420.

38. Reilly, F. (1973). Further evidence on short-run results for new issues investors. Journal of Financial and Quantitative Analysis, 8(1), 83-90.

39. Ritter, J., \& Welch, I. (2002). A review of IPO activity, pricing and allocation. The Journal of Finance, 67(4), 1795-1828.

40. Ritter, J. (1991). The long run performance of initial public offerings. The Journal of Finance, 46(1), 3-27.

41. Rock, K. (1986). Why new issues are underpriced. Journal of Financial Economics, 15(1-2), 187-212.

42. Schultz, P. (2001). Pseudo market timing and the long run underperformance of IPOs. (Working paper). University of Notre Dame.

43. Stoll, H., \& Curley, A. (1970). Small business and the new issues market for equities. Journal of Financial and Quantitative Analysis, 5(3), 309-322.

44. Su, C., \& Bangassa, K. (2011). The impact of underwriter reputation on initial returns and long-run performance of Chinese IPOs. Journal of International Financial Markets, Institutions and Money, 21(5), 760-791.

45. Van Rensburg, P., \& Robertson, M. (2003). Style characteristics and the cross-section of JSE returns. Investment Analysts Journal, 57, 7-15.

46. Welch, I. (1992). Sequential sales, learning, and cascades. Journal of Finance, 47(2), 695-732.

47. Yermack, D. (1996). Higher market valuation of companies with a small board of directors. Journal of Financial Economics, 40(2), 185-211. 
NOTES 